\title{
The Effect of ULO and NA Storage on Changes in the Quality of Apple Fruit (Malus domestica Borkh.) during Shelf Life
}

\author{
Aleksandra Korićanac ${ }^{1, *}$, Nemanja Miletić ${ }^{2}$, Branko Popović ${ }^{1}$, Olga Mitrović $^{1}$, Milan Lukić ${ }^{1}$, \\ Marijana Pešaković ${ }^{1}$ and Jelena Tomić ${ }^{1}$ \\ 1 Fruit Research Institute, Kralja Petra I/9, 32000 Čačak, Serbia; bpopovic@institut-cacak.org (B.P.); \\ omitrovic@institut-cacak.org (O.M.); mlukic@institut-cacak.org (M.L.); mpesakovic@institut-cacak.org (M.P.); \\ jtomic@institut-cacak.org (J.T.) \\ 2 Faculty of Agronomy, Cara Dušana 34, 32000 Čačak, Serbia; n.m.miletic@kg.ac.rs \\ * Correspondence: akoricanac@institut-cacak.org; Tel.: +381-32-321375
}

Received: 27 November 2019; Accepted: 20 December 2019; Published: 23 December 2019

\begin{abstract}
In order to preserve the quality of apple fruit, it is crucial to choose the most suitable storage technology. Nevertheless, it is also important to maintain the quality of apples during the shelf life period. In this study, changes in various biochemical quality parameters of 'Golden Delicious' and 'Idared' apples during a prolonged shelf life period, after conventional normal atmosphere (NA) and ultra-low oxygen (ULO) storage, were investigated. After the harvest, the fruit of examined cultivars were stored in two atmospheres for six months. Weight loss, changes in content of sugars, organic acids, total phenols, total flavonoids, pectic fractions, and antioxidant capacity were monitored. Samples were evaluated immediately after removal from the cold chambers and after 10 and 20 days of shelf life at $20^{\circ} \mathrm{C}$. 'Golden Delicious' apples stored in ULO exhibited better qualitative characteristics during 20 days of shelf life compared with apples of the same cultivar stored in NA. However, evaluated traits in 'Idared' apples from NA chambers were of higher quality in comparison with 'Idared' apples stored in the ULO atmosphere.
\end{abstract}

Keywords: apple; storage; qualitative change; shelf life

\section{Introduction}

Apple consumption has been shown to be effective in the prevention of cardiovascular diseases, diabetes, and asthma [1-3]. It is a general opinion that polyphenols are the main contributors to the biological activities of apples [4]. Nowadays, the beneficial health effects of these secondary plant metabolites are being reported $[5,6]$. Many factors, such as genotype, ripening stage, environmental conditions, and postharvest operations, affect the chemical composition and polyphenols content $[7,8]$. In order to preserve the quality of apple fruit, it is crucial to apply the most suitable storage technology. Furthermore, it is also important to minimize the loss of quality and to maintain the high nutritional value of apples during the shelf life period. In the literature, there are numerous studies referring to qualitative changes in apples during long-term cold storage, whereas only few studies at room temperature have been carried out.

The patterns of phenolic changes during storage and shelf life are various. Piretti et al. [9] noted a decrease of the most important phenolics in 'Granny Smith' apple skin either during air and controlled atmosphere storage or during one week of shelf life at $20^{\circ} \mathrm{C}$. In contrast, Bizjak et al. [10] found that phenolics in the peel increased significantly, whereas they remained constant in the pulp of apples. Veberic et al. [11] reported a decrease in the content of malic acid and phenolics in the peel during a three-week shelf life period, indicating different behaviors of phenolic compounds. 
The ability of apples to neutralize health-hazardous oxygen species is of high importance. Available evidences on the behavior of polyphenols and their contribution to the antioxidant capacity during shelf life are partly conflicting. Previous studies have shown that the majority of the antioxidant activity of fruit may originate from the flavonoids and other phenolic compounds [12,13]. However, in several studies, no correlation between the antioxidant capacity and any single phenolic compounds was found [14,15]. Since antioxidant capacity is a result of several molecules and their synergistic effects, more research is required to evaluate the effects of cold storage conditions on the retention of health-promoting compounds in apples during shelf life.

The cell wall of fruit determines the firmness, which is an important quality characteristic of apples. The structural model of the cell wall consists of a cellulose-hemicellulose network, an amorphous matrix composed of pectin, and small amounts of phenolics and proteins $[16,17]$. Since pectic substances are the most abundant macromolecules within the cell wall matrix, changes in pectin composition consequently result in changes in the firmness and texture of apples. Ben and Gaweda [18] reported high correlation coefficients between the content of protopectin and the firmness of 'Jonathan' apples.

Since storage methods affect apple quality [19], a better understanding of the relationship between applied storage conditions and biochemical processes in fruit could lead to the maintenance of apple quality during shelf life. The objective of this study was to determine the changes in quality and various biochemical parameters of 'Golden Delicious' and 'Idared' apples during a 20-day shelf life period, after conventional normal atmosphere (NA) and ultra-low oxygen (ULO) storage.

\section{Materials and Methods}

\subsection{Plant Material}

Fruit of 'Golden Delicious' and 'Idared' were collected from a commercial orchard in the village Lipnica ( $43^{\circ} 48^{\prime} 51^{\prime \prime}$ N; $20^{\circ} 26^{\prime} 52^{\prime \prime}$ E), near Čačak (Central part of Republic of Serbia). Apples were grown according to the rules of integrated fruit production and harvested at the optimum harvest date. Samples were collected in the following way: 300 fruit from each cultivar were picked randomly from 10 trees ( 30 fruit per tree). Apple trees located in the middle of the rows were used for the experiment. Trees at the border of the orchard were not used. The fruit were selected on the basis of the absence of damage and disease indicators.

Fruit of each cultivar were divided into two groups containing 150 fruit and stored for six months, either in normal atmosphere (NA) chambers at $1.5^{\circ} \mathrm{C}$ and $90 \%$ to $92 \%$ relative humidity (RH) or in ultra-low oxygen chambers $\left(1{ }^{\circ} \mathrm{C}, 0.8 \% \mathrm{O}_{2}, 1 \% \mathrm{CO}_{2}, 90 \% \mathrm{RH}\right.$ for 'Golden Delicious' apples; $1.5^{\circ} \mathrm{C}$, $1 \% \mathrm{O}_{2}, 1 \% \mathrm{CO}_{2}, 90 \% \mathrm{RH}$ for 'Idared' apples). After cold storage, apples were exposed to $20^{\circ} \mathrm{C}$ for 20 days to simulate the commonly applied commercial conditions. During this time, quality parameters were analyzed three times: Immediately after removal from the cold chambers (T1) and after 10 (T2) and 20 days of shelf life (T3). Twenty apples from each group were selected for determination of weight loss. On every sampling date, 36 apples from each group were used for laboratory analyses, conducted in triplicate.

\subsection{Weight Loss}

Weight loss was determined by periodical weighing of samples. Twenty fruit from each group were separated for the weight loss test. The weight loss (\%) was calculated using the equation:

$$
\text { Weight loss }(\%)=((\text { Fruit initial weight }- \text { Fruit weight after interval }) \times 100) / \text { Fruit initial weight }
$$

\subsection{Soluble Solids Content (SSC), Sugars Content, and Titratable Acidity (TA)}

The SSC was determined from the juice obtained from nine apples randomly chosen from each group. The SSC of the fruit was measured on a digital refractometer (model MA871, 
Milwaukee Instruments, Rocky Mount, NC 27804, USA) and the results were expressed as a percentage (\%).

Sample preparation for the determination of sugar content and TA was performed as follows: On every sampling date, nine apples from each group were chosen without a particular pattern; the fruit were cut and cored and seeds were discarded and the tissue was ground using a stainless steel blender; samples (25 $\mathrm{g}$ for each replicate) were homogenized with $100 \mathrm{~mL}$ of distilled water; after 30 min extraction at $78^{\circ} \mathrm{C}$, the mixture was diluted to $250 \mathrm{~mL}$ with distilled water. Total sugars (TS) and reducing sugars (RS) content was determined by the Luff-Schoorl method [20]. The titratable acidity (TA) was determined by neutralization of $10 \mathrm{~mL}$ of fruit extract with $0.1 \mathrm{~N} \mathrm{NaOH}$ to $\mathrm{pH} 8.2$, using phenolphthalein as the indicator. The results were expressed as grams of malic acid per $100 \mathrm{~g}$ fresh weight (g malic acid/100 $\mathrm{g} \mathrm{fw}$ ).

\subsection{Determination of Total Phenolics, Flavonoid Contents, and Antioxidant Activity}

On every sampling date, nine apples from each group were randomly chosen and combined into 3 samples, with 3 apples per sample. The tissue of samples (without core and seed) was frozen in liquid nitrogen and ground. The ground sample ( $10 \mathrm{~g}$ ) was stirred with $25 \mathrm{~mL}$ of methanol. After $30 \mathrm{~min}$ of ultrasonic extraction, the mixture was centrifuged for $5 \mathrm{~min}$ at $5000 \mathrm{rpm}$, and supernatant was filtered through a 0.45-mm Minisart filter before analysis.

The total phenolic content (TPH) was determined using a modified Folin-Ciocalteu colorimetric method [21], with results expressed as milligrams of gallic acid equivalents/100 $\mathrm{g}$ fresh weight (mg GAE/100 $\mathrm{g} \mathrm{fw}$ ). Total flavonoids (TF) were determined according to Liu et al. [22], using the aluminum chloride colorimetric method. The results were expressed as milligrams of rutin equivalents/100 $\mathrm{g}$ fresh weight (mg RE/100 g fw). Antioxidant capacity (AC) was determined by the ABTS assay. ABTS•+ radical cation scavenging activity was determined according to the method described by Re et al. [23]. Results were expressed as Trolox equivalent antioxidant capacity (mmol TE/100 g fw).

\subsection{Determination of Pectic Fractions}

Pectic fractions are pectinic acid (fraction soluble in water), pectic acid (PA) (soluble in ammonium oxalate), and protopectin (PP) (soluble in bases). Determination of pectic fraction was based on the colored reaction between fractions of pectin and carbazole in the presence of sulfuric acid. Nine apples, randomly chosen from each group, were used for the preparation of three samples (three apples per sample). The fruit were cut and cored and seeds were discarded and the tissue was ground using a stainless steel blender (model UM10ISI, Elta, Germany). Extraction of pectic fractions and colorimetric determination were performed as previously described [24] using $3 \mathrm{~g}$ of sample per replicate. The absorbance of the mixture at $525 \mathrm{~nm}$ was measured using a Beckman, USA spectrophotometer and compared to the standard curve of the prepared anhydro galacturonic acid. The contents of protopectin, pectic, and pectinic acid were expressed as milligrams per $100 \mathrm{~g}$ fresh weight $(\mathrm{mg} / 100 \mathrm{~g}$ fw).

\subsection{Statistical Analysis}

The statistical analysis was performed using STATISTICA 7.0 software (Statsoft Inc., Tulsa, OK, USA). The data were subjected to the two-way analysis of variance (ANOVA, $F$ test), followed by a comparison of means according to the Tukey's test, in order to analyze the influence of the storage type, the shelf life duration, and their interaction. The experimental design was completely randomized. Treatments were declared different at $p=0.01$ and $p=0.001$ levels of significance. All data were reported as mean \pm standard deviation (S.D.) of three replicates. 


\section{Results}

\subsection{Weight Loss}

The impact of the storage type and shelf life duration on the weight loss of 'Golden Delicious' and 'Idared' fruit is presented in Figure 1. The weight loss of fruit of the examined apple cultivars increased during shelf life. According to the results, the weight loss in 'Golden Delicious' apples was considerably higher in fruit stored under NA storage conditions. 'Idared' apples stored in ULO chambers exhibited higher weight loss after either 10 or 20 days of shelf life.
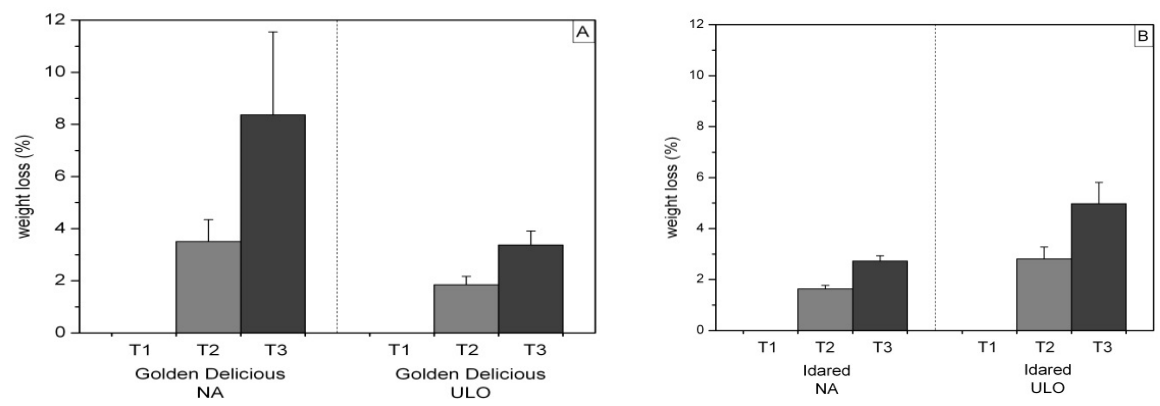

Figure 1. Impact of storage type on weight loss (\%) in (A) 'Golden Delicious' and (B) 'Idared' apples after 10 (T2) and 20 days (T3) of shelf life at $20^{\circ} \mathrm{C}$. Values represent mean \pm standard deviation (S.D.) of measurements made on 20 fruit per storage type and shelf life period.

\subsection{SSC, Sugars Content, and TA}

A decrease in SSC, total sugars, and reducing sugars in 'Golden Delicious' apples stored under NA storage conditions was determined after 20 days of shelf life. In 'Golden Delicious' apples from the ULO chamber, fluctuations in the contents of soluble solids, total sugars, and reducing sugars were observed (Figure 2). Although an increase of SSC and sugars content was expected, a slight decrease of these parameters in both examined cultivars was noticed (Figure 2). The most striking change was the increase of TS and RS contents in 'Golden Delicious' apples from the NA chamber after 10 days of shelf life.
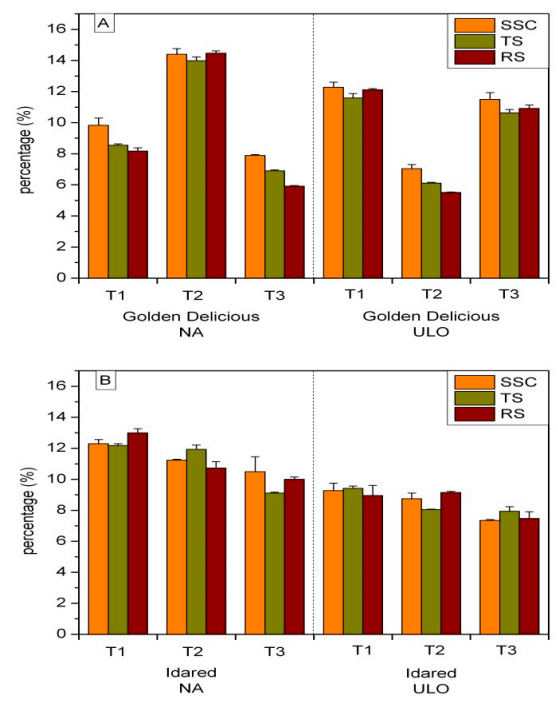

Figure 2. Impact of storage type on soluble solids content (SSC), total sugars (TS), and reducing sugars (RS) content expressed in percentage (\%) in (A) 'Golden Delicious' and (B) 'Idared' apples after 10 (T2) and 20 days (T3) of shelf life at $20^{\circ} \mathrm{C}$. Values represent mean \pm standard deviation (S.D.) of three replicates per storage type and shelf life period. 
As for titratable acidity, 'Golden Delicious' apples from ULO chambers had a higher total acids content compared to the fruit of the same cultivar stored under NA conditions. In 'Golden Delicious' apples from the ULO chamber and 'Idared' apples from the NA chamber, a slight increase in TA was noticed (Figure 3).
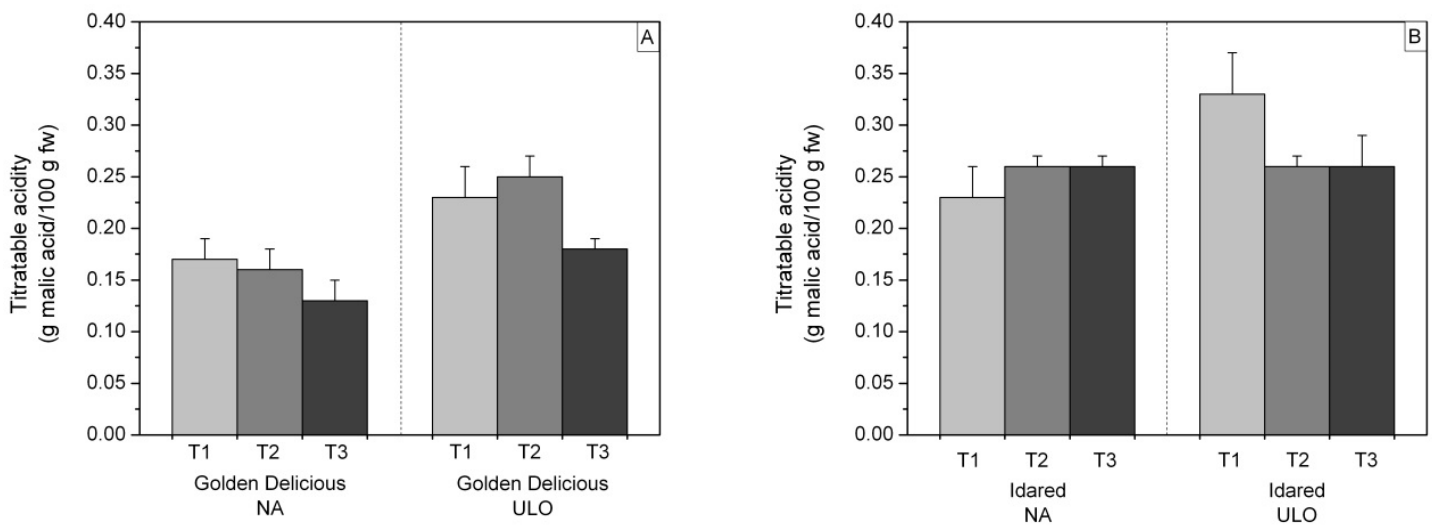

Figure 3. Impact of storage type on titratable acidity (TA) expressed in percentage (\%) in (A) 'Golden Delicious' and (B) 'Idared' apples after 10 (T2) and 20 days (T3) of shelf life at $20{ }^{\circ} \mathrm{C}$. Values represent mean \pm standard deviation (S.D.) of three replicates per storage type and shelf life period.

During 10 and 20 days of shelf life, the concentration of total acids in both groups of 'Idared' apples was relatively constant while the content of total sugars and reducing sugars showed only minor changes.

\subsection{Content of Total Phenolics, Total Flavonoids, and Antioxidant Capacity}

The analysis of variance showed a significant effect of storage conditions on total phenolics, total flavonoids content, and antioxidant capacity in the fruit of both examined cultivars (Table 1 , Table 2). The obtained results indicate that the content of different health-promoting compounds of apples change significantly during shelf life and depends on the applied cold storage technique.

Table 1. The effect of storage type and shelf life duration on total phenolics, total flavonoids content, and antioxidant capacity in 'Golden Delicious' apples.

\begin{tabular}{|c|c|c|c|c|}
\hline \multicolumn{2}{|c|}{ Factor } & \multirow{3}{*}{$\begin{array}{c}\begin{array}{c}\text { Total Phenolics } \\
\text { (mg GAE/100 g fw) }\end{array} \\
68.61 \pm 19.28 \mathrm{~b} \\
110.24 \pm 9.14 \mathrm{a}\end{array}$} & \multirow{3}{*}{$\begin{array}{c}\text { Total Flavonoids } \\
\text { (mg R/100 g fw) }\end{array}$} & \multirow{3}{*}{$\begin{array}{c}\begin{array}{c}\text { Antioxidant } \\
\text { Capacity }\end{array} \\
\text { (mmol TE/100g fw) } \\
0.3948 \pm 0.2208 \mathrm{~b} \\
0.5208 \pm 0.2835 \mathrm{a}\end{array}$} \\
\hline & NA storage & & & \\
\hline Storage type (A) & ULO storage & & & \\
\hline & 0 days $(\mathrm{T} 1)$ & $104.46 \pm 15.12 \mathrm{a}$ & $25.55 \pm 8.73 b$ & $0.1577 \pm 0.0404 \mathrm{c}$ \\
\hline Shelt life duration & 10 days (T2) & $87.74 \pm 26.59 \mathrm{~b}$ & $32.26 \pm 4.20 \mathrm{a}$ & $0.4800 \pm 0.0597 \mathrm{~b}$ \\
\hline & 20 days (T3) & $76.07 \pm 29.38 c$ & $24.19 \pm 7.50 \mathrm{~b}$ & $0.7358 \pm 0.1199 \mathrm{a}$ \\
\hline \multirow{6}{*}{$(\mathrm{A} \times \mathrm{B})$} & $\mathrm{NA} \times \mathrm{T} 1$ & $92.68 \pm 5.36 b$ & $17.82 \pm 3.38 \mathrm{c}$ & $0.1247 \pm 0.0142 \mathrm{e}$ \\
\hline & $\mathrm{NA} \times \mathrm{T} 2$ & $63.69 \pm 1.25 c$ & $28.64 \pm 1.17 b$ & $0.4300 \pm 0.0229 \mathrm{~d}$ \\
\hline & $\mathrm{NA} \times \mathrm{T} 3$ & $49.46 \pm 1.43 c$ & $17.52 \pm 0.79 c$ & $0.6297 \pm 0.0167 b$ \\
\hline & $\mathrm{ULO} \times \mathrm{T} 1$ & $116.25 \pm 11.25 \mathrm{a}$ & $33.27 \pm 0.23 \mathrm{ab}$ & $0.1907 \pm 0.0248 \mathrm{e}$ \\
\hline & $\mathrm{ULO} \times \mathrm{T} 2$ & $111.78 \pm 5.57 \mathrm{a}$ & $35.87 \pm 1.85 \mathrm{a}$ & $0.5300 \pm 0.0300 c$ \\
\hline & $\mathrm{ULO} \times \mathrm{T} 3$ & $102.68 \pm 5.71 \mathrm{ab}$ & $30.86 \pm 2.51 \mathrm{ab}$ & $0.8418 \pm 0.0440 a$ \\
\hline \multicolumn{5}{|c|}{ ANOVA } \\
\hline \multicolumn{2}{|c|}{ A } & $* * *$ & $* * *$ & $* * *$ \\
\hline \multicolumn{2}{|c|}{ B } & $* * *$ & $* * *$ & $* * *$ \\
\hline \multicolumn{2}{|c|}{$\mathrm{A} \times \mathrm{B}$} & ** & ** & ** \\
\hline
\end{tabular}

The presence of equal letters in the same column indicates that there is no significant difference according to the Tukey's test. ${ }^{* * *}$ statistically significant differences at $p \leq 0.001 ;{ }^{* *}$ statistically significant differences at $p \leq 0.01$. 
Table 2. The effect of storage type and shelf life duration on total phenolics, total flavonoids contents, and antioxidant capacity in 'Idared' apples.

\begin{tabular}{|c|c|c|c|c|}
\hline Factor & & $\begin{array}{c}\text { Total Phenolics } \\
\text { (mg GAE/100 g } \\
\text { fw) }\end{array}$ & $\begin{array}{l}\text { Total Flavonoids } \\
\text { (mg R/100 } \mathrm{g} \mathrm{fw})\end{array}$ & $\begin{array}{c}\text { Antioxidant } \\
\text { Capacity } \\
(\mathrm{mmol} T E / 100 \mathrm{~g} \mathrm{fw})\end{array}$ \\
\hline \multirow{2}{*}{ Storage type (A) } & NA storage & $108.37 \pm 38.70 \mathrm{a}$ & $40.07 \pm 8.69 a$ & $0.6782 \pm 0.2183 a$ \\
\hline & ULO storage & $77.76 \pm 14.58 \mathrm{~b}$ & $30.13 \pm 1.86 \mathrm{~b}$ & $0.5589 \pm 0.2828 b$ \\
\hline \multirow{3}{*}{$\begin{array}{l}\text { Shelf life duration } \\
\text { (B) }\end{array}$} & 0 days (T1) & $103.87 \pm 49.90 \mathrm{a}$ & $39.29 \pm 11.77 \mathrm{a}$ & $0.3197 \pm 0.1362 c$ \\
\hline & 10 days (T2) & $74.02 \pm 14.51 \mathrm{~b}$ & $30.15 \pm 0.95 c$ & $0.6500 \pm 0.0235 b$ \\
\hline & 20 days (T3) & $101.31 \pm 14.92 \mathrm{a}$ & $35.86 \pm 4.98 c$ & $0.8861 \pm 0.0607 \mathrm{a}$ \\
\hline \multirow{6}{*}{$(\mathrm{A} \times \mathrm{B})$} & $\mathrm{NA} \times \mathrm{T} 1$ & $149.34 \pm 4.46 \mathrm{a}$ & $49.97 \pm 0.69 a$ & $0.4405 \pm 0.0104 \mathrm{~d}$ \\
\hline & $\mathrm{NA} \times \mathrm{T} 2$ & $61.07 \pm 4.80 \mathrm{~d}$ & $29.93 \pm 4.31 c$ & $0.6533 \pm 0.0333 c$ \\
\hline & $\mathrm{NA} \times \mathrm{T} 3$ & $114.70 \pm 3.58 b$ & $40.31 \pm 0.61 b$ & $0.9410 \pm 0.0083 \mathrm{a}$ \\
\hline & $\mathrm{ULO} \times \mathrm{T} 1$ & $58.39 \pm 0.94 \mathrm{~d}$ & $28.61 \pm 1.87 c$ & $0.1988 \pm 0.0490 \mathrm{e}$ \\
\hline & $\mathrm{ULO} \times \mathrm{T} 2$ & $86.96 \pm 0.36 c$ & $30.37 \pm 1.43 c$ & $0.6467 \pm 0.0153 c$ \\
\hline & $\mathrm{ULO} \times \mathrm{T} 3$ & $87.92 \pm 2.32 c$ & $31.41 \pm 1.51 \mathrm{c}$ & $0.8312 \pm 0.0094 b$ \\
\hline \multicolumn{5}{|c|}{ ANOVA } \\
\hline \multicolumn{2}{|l|}{ A } & $* * *$ & $* * *$ & $* * *$ \\
\hline \multicolumn{2}{|l|}{ B } & $* * *$ & $* * *$ & $* * *$ \\
\hline \multicolumn{2}{|l|}{$A \times B$} & $* * *$ & $* * *$ & $* * *$ \\
\hline
\end{tabular}

The presence of equal letters in the same column indicates that there is no significant difference according to the Tukey's test. ${ }^{* * *}$ statistically significant differences at $p \leq 0.001$.

'Golden Delicious' apples from the ULO chamber exhibited higher antioxidant activity and total phenolics and flavonoids content in comparison with apples from the NA chamber (Table 1). After 20 days of shelf life, levels of total phenolics decreased by $46.63 \%$ in 'Golden Delicious' apples from the NA chamber and by $11.67 \%$ in 'Golden Delicious' apples from the ULO chamber. Total flavonoids showed minor changes. The relatively low antioxidant capacity observed immediately after removal from cold chambers increased considerably during 20 days at $20^{\circ} \mathrm{C}$. Interestingly, after the shelf life period, higher values for antioxidant capacity were determined in combination with a decrease in phenolics content.

Statistically significant higher values of total phenolics and flavonoids contents were observed in 'Idared' apples stored under NA conditions in comparison with 'Idared' apples from the ULO chamber. Shelf life led to an increase in antioxidant capacity in both groups of 'Idared' apples (Table 2). Storage under the ULO atmosphere led to low increases of both total phenolics and total flavonoids content during shelf life.

The antioxidant capacity in all four examined groups of apples increased. In some groups, the contents of total phenolics and flavonoids decreased significantly during shelf life.

\subsection{Pectic Fractions}

Transformation of water-insoluble protopectin into water-soluble components, pectinic and pectic acids, leads to disintegration of the primary cell wall and consequently to softening of fresh fruit. A significant effect of the storage atmosphere on the pectic solubilization, particularly in 'Golden Delicious' apples, was observed (Table 3). The content of protopectin in 'Golden Delicious' apples from the ULO chamber was higher by $33.77 \%$ in comparison with apples stored under NA conditions. 
Table 3. The effect of storage type and shelf life duration on the content of pectic fractions in 'Golden Delicious' apples.

\begin{tabular}{|c|c|c|c|c|c|}
\hline Factor & & $\begin{array}{l}\text { Pectinic Acid } \\
(\mathrm{mg} / \mathbf{1 0 0} \mathrm{g} \text { fw) }\end{array}$ & $\begin{array}{c}\text { Pectic Acid } \\
(\mathrm{mg} / \mathbf{1 0 0} \mathrm{g} \mathrm{fw})\end{array}$ & $\begin{array}{l}\text { Protopectin } \\
(\mathrm{mg} / \mathbf{1 0 0} \mathrm{g} \mathrm{fw})\end{array}$ & $\begin{array}{l}\text { Pectinic Acid } \\
\text { /Protopectin }\end{array}$ \\
\hline Storage type & NA storage & $90.92 \pm 53.13 \mathrm{a}$ & $51.16 \pm 40.31 \mathrm{a}$ & $44.46 \pm 14.22 b$ & $2.75 \pm 2.58 \mathrm{a}$ \\
\hline (A) & ULO storage & $63.30 \pm 18.24 b$ & $30.25 \pm 20.04 b$ & $67.13 \pm 34.88 \mathrm{a}$ & $1.66 \pm 1.59 \mathrm{~b}$ \\
\hline \multirow{3}{*}{$\begin{array}{c}\text { Shelf life } \\
\text { duration (B) }\end{array}$} & 0 days (T1) & $43.46 \pm 5.61 c$ & $17.36 \pm 4.48 c$ & $71.57 \pm 14.88 \mathrm{a}$ & $0.64 \pm 0.18 b$ \\
\hline & 10 days (T2) & $67.91 \pm 3.65 b$ & $24.18 \pm 4.29 b$ & $71.86 \pm 25.79 \mathrm{a}$ & $1.05 \pm 0.35 b$ \\
\hline & 20 days (T3) & $119.95 \pm 45.03 \mathrm{a}$ & $80.58 \pm 26.62 \mathrm{a}$ & $23.96 \pm 4.58 \mathrm{~b}$ & $4.94 \pm 1.46 \mathrm{a}$ \\
\hline \multirow{6}{*}{$(\mathrm{A} \times \mathrm{B})$} & $\mathrm{NA} \times \mathrm{T} 1$ & $46.50 \pm 4.00 \mathrm{c}$ & $21.43 \pm 0.64 c$ & $58.14 \pm 2.79 c$ & $0.80 \pm 0.03 c$ \\
\hline & $\mathrm{NA} \times \mathrm{T} 2$ & $65.72 \pm 2.54 b$ & $27.33 \pm 3.05 c$ & $48.36 \pm 2.63 \mathrm{~d}$ & $1.36 \pm 0.13 c$ \\
\hline & $\mathrm{NA} \times \mathrm{T} 3$ & $160.54 \pm 9.35 a$ & $104.72 \pm 3.20 \mathrm{a}$ & $25.87 \pm 5.04 \mathrm{e}$ & $6.10 \pm 1.09 \mathrm{a}$ \\
\hline & $\mathrm{ULO} \times \mathrm{T} 1$ & $40.43 \pm 5.93 c$ & $13.29 \pm 0.21 \mathrm{~d}$ & $85.00 \pm 2.21 b$ & $0.48 \pm 0.08 c$ \\
\hline & $\mathrm{ULO} \times \mathrm{T} 2$ & $70.11 \pm 3.54 b$ & $21.03 \pm 2.61 c$ & $95.34 \pm 1.59 \mathrm{a}$ & $0.74 \pm 0.03 c$ \\
\hline & $\mathrm{ULO} \times \mathrm{T} 3$ & $79.37 \pm 6.45 b$ & $56.44 \pm 3.52 b$ & $21.05 \pm 1.25 \mathrm{e}$ & $3.77 \pm 0.27 b$ \\
\hline \multicolumn{6}{|c|}{ ANOVA } \\
\hline A & & $* * *$ & $* * *$ & $* * *$ & $* * *$ \\
\hline B & & $* * *$ & $* * *$ & $* * *$ & $* * *$ \\
\hline$A \times B$ & & $* * *$ & $* * *$ & $* * *$ & $* *$ \\
\hline
\end{tabular}

The presence of equal letters in the same column indicates that there is no significant difference according to the Tukey's test. ${ }^{* * *}$ statistically significant differences at $p \leq 0.001 ;{ }^{* *}$ statistically significant differences at $p \leq 0.01$.

'Golden Delicious' apples from the ULO chamber had a higher content of protopectin on all analysis dates compared to 'Golden Delicious' apples stored under NA conditions. However, storage atmosphere did not affect the content of protopectin in 'Idared' apples (Table 4).

Table 4. The effect of storage type and shelf life duration on the content of pectic fractions in 'Idared' apples.

\begin{tabular}{|c|c|c|c|c|c|}
\hline Factor & & $\begin{array}{l}\text { Pectinic Acid } \\
(\mathrm{mg} / \mathbf{1 0 0} \mathrm{g} \text { fw) }\end{array}$ & $\begin{array}{c}\text { Pectic Acid } \\
\text { (mg/100 g fw) }\end{array}$ & $\begin{array}{l}\text { Protopectin } \\
(\mathrm{mg} / \mathbf{1 0 0} \mathrm{g} \mathrm{fw})\end{array}$ & $\begin{array}{l}\text { Pectinic Acid } \\
\text { /Protopectin }\end{array}$ \\
\hline $\begin{array}{c}\text { Storage type } \\
\text { (A) }\end{array}$ & $\begin{array}{l}\text { NA storage } \\
\text { ULO storage }\end{array}$ & $\begin{array}{c}127.66 \pm 64.68 \mathrm{a} \\
80.66 \pm 48.91 \mathrm{~b}\end{array}$ & $\begin{array}{l}47.46 \pm 32.64 \mathrm{a} \\
32.54 \pm 9.63 \mathrm{~b}\end{array}$ & $\begin{array}{l}48.21 \pm 23.09 \mathrm{a} \\
49.84 \pm 32.99 \mathrm{a}\end{array}$ & $\begin{array}{l}4.77 \pm 5.16 a \\
1.62 \pm 0.81 b\end{array}$ \\
\hline $\begin{array}{c}\text { Shelf life } \\
\text { duration (B) }\end{array}$ & $\begin{array}{l}0 \text { days }(\mathrm{T} 1) \\
10 \text { days }(\mathrm{T} 2) \\
20 \text { days }(\mathrm{T} 3)\end{array}$ & $\begin{array}{c}62.53 \pm 18.48 \mathrm{~b} \\
70.46 \pm 22.37 \mathrm{~b} \\
179.48 \pm 37.64 \mathrm{a}\end{array}$ & $\begin{array}{c}28.04 \pm 3.77 b \\
24.36 \pm 1.79 c \\
67.61 \pm 25.60 a\end{array}$ & $\begin{array}{l}62.04 \pm 5.75 b \\
72.66 \pm 5.65 a \\
12.38 \pm 6.88 c\end{array}$ & $\begin{array}{c}1.04 \pm 0.39 b \\
0.99 \pm 0.39 b \\
17.77 \pm 7.27 a\end{array}$ \\
\hline$(\mathrm{A} \times \mathrm{B})$ & $\begin{array}{l}\mathrm{NA} \times \mathrm{T} 1 \\
\mathrm{NA} \times \mathrm{T} 2 \\
\mathrm{NA} \times \mathrm{T} 3 \\
\mathrm{ULO} \times \mathrm{T} 1 \\
\mathrm{ULO} \times \mathrm{T} 2 \\
\mathrm{ULO} \times \mathrm{T} 3\end{array}$ & $\begin{array}{c}79.07 \pm 3.00 \mathrm{c} \\
90.66 \pm 5.11 \mathrm{c} \\
213.23 \pm 10.94 \mathrm{a} \\
46.00 \pm 4.93 \mathrm{~d} \\
50.25 \pm 0.18 \mathrm{~d} \\
145.73 \pm 2.19 \mathrm{~b}\end{array}$ & $\begin{array}{l}25.43 \pm 0.50 \mathrm{~d} \\
25.97 \pm 0.14 \mathrm{~d} \\
90.97 \pm 0.23 \mathrm{a} \\
30.64 \pm 3.86 \mathrm{c} \\
22.74 \pm 0.45 \mathrm{~d} \\
44.25 \pm 1.02 \mathrm{~b}\end{array}$ & $\begin{array}{c}57.21 \pm 3.57 \mathrm{c} \\
68.86 \pm 6.04 \mathrm{ab} \\
18.55 \pm 1.72 \mathrm{~d} \\
60.86 \pm 0.50 \mathrm{~b} \\
76.45 \pm 0.32 \mathrm{a} \\
6.20 \pm 1.11 \mathrm{e}\end{array}$ & $\begin{array}{c}1.38 \pm 0.12 c \\
1.33 \pm 0.19 c \\
11.58 \pm 1.41 b \\
0.69 \pm 0.07 c \\
0.66 \pm 0.00 c \\
23.95 \pm 3.99 a\end{array}$ \\
\hline \multicolumn{6}{|c|}{ ANOVA } \\
\hline A & & $* * *$ & $* * *$ & ns & $* * *$ \\
\hline B & & $* * *$ & $* * *$ & $* * *$ & $* * *$ \\
\hline$A \times B$ & & $* * *$ & $* * *$ & $* * *$ & $* * *$ \\
\hline
\end{tabular}

The presence of equal letters in the same column indicates that there is no significant difference according to the Tukey's test. ${ }^{* * *}$ statistically significant differences at $p \leq 0.001 ;$ ns - no significant difference.

After 20 days of shelf life, the concentration of protopectin decreased dramatically in both examined cultivars, with a simultaneous increase of the pectinic acid:protopectin ratio. 


\section{Discussion}

In order to satisfy consumers' needs and expectations, the quality of apple fruit should be maintained after removal from cold chambers. The shelf life of fruit is affected by a number of factors, such as growing, harvesting operations, and storage conditions [25-29]. In the present study, we evaluated the effect of applied cold storage on qualitative changes in apples during shelf life in order to determine the most suitable storage technique for the examined apple cultivars.

Since metabolic processes continue after harvest, apple fruit lose water during storage and shelf life, which results in weight loss. Kader [30] reported that increasing the storage duration resulted in an increased percentage of fruit weight loss. This is in compliance with the obtained results.

The SSC of apples is an important quality factor, which determines fruit taste [31]. In 'Golden Delicious' apples from the NA chamber, SSC increased after 10 days of shelf life, which can be attributed to starch degradation and moisture loss. Similar results were obtained by Crouch [32] and Farooq [33]. On the other hand, a decrease in SSC was registered in 'Idared' apples. In the present study, a decrease in total sugars after 20 days of shelf life was noticed in both examined cultivars. In 'Idared' apples, the content of reducing sugars mainly showed minor changes during shelf life. This result is in agreement with Veberic et al. [11], who reported that the content of sugars in apple pulp remained constant during a 3-week shelf life period. However, Defilippi [34] noted a higher content of total sugars as well as of sucrose and fructose in apples after 14 days at $20^{\circ} \mathrm{C}$.

Jan and Rab [35] reported that increasing the storage duration will result in decreased titratable acidity of apple juice, which is in compliance with the present study. Pre-Aymard [36] also noticed a linear decrease of TA during shelf life. The changes in TA are considerably affected by the rate of metabolism [37].

Different antioxidant components in fruit may in various ways significantly contribute to the total antioxidant activity. Many authors have studied the correlation between total phenolic content and antioxidant activity in various fruits [38-41]. Kevers et al. [38] observed a high correlation between antioxidant capacity and total phenolics in various tested fruits. Vieira et al. [40] reported that the total phenol content and antioxidant activity were significantly correlated in 11 apple cultivars. However, Miletić et al. [41] reported that plum fruit containing the highest total phenolics did not necessarily exhibit the highest antioxidant capacity. Similarly, no clear trend between the phenolics content and antioxidant activity was observed in the present study. In both examined cultivars, antioxidant capacity increased significantly regardless of the type of storage. However, total phenolics and total flavonoids content in 'Golden Delicious' apples decreased after 20 days at $20^{\circ} \mathrm{C}$. The flavonoids, primarily quercetin and catechin, are common polyphenoloxidase substrates [42]. Therefore, the decrease of phenolics content could be related to oxidation by polyphenoloxidase. These results are consistent with the findings of Lattanzio et al. [43], who determined a decrease in phenolics, particularly phloridzin, after 10 days of shelf life in 'Golden Delicious' fruit. An increase of the total antioxidant capacity during the shelf life period in 'Idared' apples was followed by an increase of the total phenolics and flavonoids content. In agreement with this, Bizjak et al. [10] detected a higher amount of all phenolic groups in the apple peel after three weeks of shelf life. In contrast to the results obtained in the present study, Veberic et al. [11] found no changes of phenolics in the apple peel of cultivars 'Jonagold' and 'Golden Delicious' after three weeks of the shelf life period. Similar results were achieved by Matthes and Schmitz-Eiberger [28], who noted no changes in the phenolics content during 14 days at $20^{\circ} \mathrm{C}$. Since antioxidant activity is a result of several phytochemicals present in the fruit and their synergistic effect, the lack of a correlation between antioxidant capacity and total phenolics and flavonoid contents might be explained by the synthesis of other antioxidants during cold storage and shelf life.

According to the results obtained, storage conditions considerably affected the contents of total phenols, flavonoids, and antioxidant capacity in both examined cultivars. 'Golden Delicious' apples from the ULO chamber exhibited higher total phenolics, total flavonoids contents, and also higher antioxidant activity in comparison with apples from the NA chamber. However, in 'Idared' apples, 
regular NA storage resulted in a higher antioxidant capacity and total phenolics either immediately after removal from the cold chamber or after 20 days of shelf life. In contrast to this, Awad and De Jager [25] observed no significant changes in flavonoid content during 30 weeks of storage under a controlled atmosphere and cold conditions in apple cultivars 'Jonagold' and 'Elstar'. In disagreement with this, Leja et al. [44] reported that additional storage of apples at $16{ }^{\circ} \mathrm{C}$ after four months under controlled atmosphere cold storage led to an increase in the total phenol content and maintenance of antioxidant activity.

Pectic substances have a role in the adhesion between cells. Therefore, changes in pectic composition result in changes in fruit texture and decreased adhesion between cells $[45,46]$. During apple softening, solubilization and depolymerization of pectic fractions occur. In the present study, in both apple cultivars, an increase of water-soluble pectic fractions and a decrease of protopectin were observed. In 'Golden Delicious' apples stored under ULO conditions, an increase of water-soluble pectinic acid and a decrease of protopectin during shelf life were lower compared to 'Golden Delicious' apples from the NA chamber. This is in agreement with the results reported by De Smedt et al. and Siddiqui et al. $[47,48]$, who found that both the decrease in total pectin and hemicellulose and the increase in water-soluble pectin were the lowest in ULO conditions, higher in the controlled atmosphere, and the highest in the normal atmosphere. On the other hand, storage conditions did not statistically significantly affect the content of protopectin in 'Idared' apples. However, after 20 days of shelf life, the pectinic acid:protpectin ratio was considerably higher in 'Idared' apples stored under ULO conditions.

\section{Conclusions}

Since ULO cold storage is expensive and not so available in developing countries, it is crucial to determine which apple cultivars must be stored under ultra-low oxygen atmosphere and which could be stored in NA without losing quality. In the present study, by monitoring the changes in several qualitative parameters of two apple cultivars, we evaluated the effects of cold storage conditions on apple quality during shelf life. It was found that various qualitative parameters changed differently, depending on the applied storage technique. 'Golden Delicious' apples from the ULO chamber had a lower weight loss and significantly higher content of total phenols, flavonoids, and antioxidant capacity, compared with fruit stored in NA. However, 'Idared' apples stored under NA conditions exhibited better quality traits during shelf life in comparison with fruit from the ULO chamber.

Author Contributions: Conceptualization, A.K., N.M. and M.L.; methodology N.M.; software, A.K.; validation., N.M.; formal analysis, B.P.; investigation, A.K., O.M. and J.T.; resources, A.K., N.M., J.T. and O.M.; data curation, A.K.; writing — original draft preparation, A.K.; writing - review and editing, N.M., M.P. and B.P.; visualization, A.K., M.L.; supervision A.K., N.M.; project administration, M.P.; funding acquisition, M.L., M.P. All authors have read and agreed to the published version of the manuscript.

Funding: This research received no external funding.

Acknowledgments: This study is the part of the project TR No. 31093, financed by Ministry of Education, Science and Technological Development of the Republic of Serbia.

Conflicts of Interest: The authors declare no conflict of interest.

\section{References}

1. Boyer, J.; Liu, R.H. Apple phytochemicals and their health benefits. Nutr. J. 2004, 3, 5. [CrossRef] [PubMed]

2. Ferretti, G.; Neri, D.; Bacchetti, T. Effect of Italian sour cherry (Prunus cerasus L.) on the formation of advanced glycation end products and lipid peroxidation. Food Nutr. Sci. 2014, 5, 1568-1576.

3. Hyson, D.A. A comprehensive review of apples and apple components and their relationship to human health. Adv. Nutr. 2011, 2, 408-420. [CrossRef] [PubMed]

4. Lee, K.W.; Kim, Y.J.; Kim, D.O.; Lee, H.J.; Lee, C.Y. Major phenolics in apple and their contribution to the total antioxidant capacity. J. Agric. Food Chem. 2003, 51, 6516-6520. [CrossRef] 
5. Scalbert, A.; Johnson, I.T.; Saltmarsh, M. Polyphenols: Antioxidants and beyond. Am. J. Clin. Nutr. 2005, 81, 2155-2175. [CrossRef]

6. Kevers, C.; Pincemail, J.; Tabart, J.; Defraigne, J.; Dommes, J. Influence of cultivar, harvest time, storage conditions and peeling on the antioxidant capacity and phenolic and ascorbic acid contents of apples and pears. J. Agric. Food Chem. 2011, 59, 6165-6171. [CrossRef]

7. Lavelli, V. Combined effect of storage temperature and water activity on the antiglycoxidative properties and color of dehydrated apples. J. Agric. Food Chem. 2009, 57, 11491-11497. [CrossRef]

8. Tsao, R.; Yang, R.; Young, J.C.; Zhu, H. Polyphenolic profiles in eight apple cultivars using high-performance liquid chromatography (HPLC). J. Agric. Food Chem. 2003, 51, 6347-6353. [CrossRef]

9. Piretti, M.V.; Gallerani, G.; Pratella, G.C. Polyphenol fate and superficial scald in Apple. Postharvest Biol. Technol. 1994, 4, 213-224. [CrossRef]

10. Bizjak, J.; Slatnar, A.; Stampar, F.; Veberic, R. Changes in Quality and Biochemical Parameters in 'Idared' apples during Prolonged Shelf Life and 1-MCP treatment. J. Food Sci. Technol. 2012, 18, 569-577. [CrossRef]

11. Veberic, R.; Schmitzer, V.; Mikulic-Petkovsek, M.; Stampar, F. Impact of shelf life on content of primary and secondary metabolites in apple (Malus domestica Borkh.). J. Food Sci. 2010, 75, 461-468. [CrossRef] [PubMed]

12. Gao, G.; Sofic, E.; Prior, R.L. Antioxidant capacity of tea and common vegetables. J. Agric. Food Chem. 1996, 44, 3426-3431.

13. Wang, H.; Gao, G.; Prior, R.L. Total antioxidant capacity of fruits. J. Agric. Food Chem. 1996, 44, 701-705. [CrossRef]

14. Van Der Sluis, A.A.; Dekker, M.; De Jager, A.; Jonegen, W.M.F. Activity and concentration of polyphenolic antioxidants in apple: Effect of cultivar, harvest year and storage conditions. J. Agric. Food Chem. 2001, 49, 3606-3613. [CrossRef]

15. Schmitz-Eiberger, M.; Weber, V.; Treutter, D.; Baab, G.; Lorenz, J. Bioactive components in fruits from different apple varieties. J. Appl. Bot. 2003, 77, 167-171.

16. Bidhendi, A.J.; Geitmann, A. Relating the mechanics of the primary plant cell wall to morphogenesis. J. Exp. Bot. 2016, 67, 449-461. [CrossRef]

17. Guillon, F.; Moïse, A.; Quemener, B. Remodeling of pectin and hemicellulose in tomato pericarp during fruit growth. Plant Sci. 2017, 257, 48-62. [CrossRef]

18. Ben, J.; Gaweda, M. Changes of pectic compounds in Jonathan apples under various storage conditions. Acta Physiol. Plant. 1985, 7, 45-54.

19. Nour, V.; Ionica, E. Study concerning the influence of the electroionical technology on the apples long-term storage. JE Prot. Ec. 2002, 3, 863-866.

20. Tanner, H. Getränke Analytik; Verlag Heller Chemie: Schwäbisch Hall, Germany, 1979.

21. Singleton, V.L.; Orthofer, R.; Lamuela-Raventos, R.M. Analysis of total phenols and other oxidation substrates and antioxidants by means of Folin-Ciocalteu reagent. Methods Enyzmol. 1999, 299, 152-178.

22. Liu, M.; Li, X.Q.; Weber, C.; Lee, C.Y.; Brown, J.; Liu, R.H. Antioxidant and antiproliferative activities of raspberries. J. Agric. Food Chem. 2002, 50, 2926-2930. [CrossRef] [PubMed]

23. Re, R.; Pellegrinni, N.; Proteggente, A.; Pannala, A.; Yang, M.; Rice-Evans, C. Antioxidant activity applying an improved ABTS radical cation decolorization assay. Free Radic. Biol. Med. 1999, 26, 1231-1237. [CrossRef]

24. Dekker, R.F.H.; Richards, G.N. Determination of pectic substances in plant material. J. Sci. Food. Agric. 1972, 23, 475-483. [CrossRef] [PubMed]

25. Awad, M.A.; De Jager, A. Flavonoid and chlorogenic acid levels in skin of Jonagold and Elstar apples during and after regular ultra-low oxygen storage. Postharvest Biol. Technol. 2000, 20, 15-24. [CrossRef]

26. Golding, J.B.; McGlasson, W.B.; Wyllie, S.G.; Leach, D.N. Fate of apple peel phenolics during cool storage. J. Agric. Food Chem. 2001, 49, 2283-2289. [CrossRef]

27. Napolitano, A.; Cascone, A.; Graziani, G.; Ferracane, R.; Scalfi, L.; Divaio, C.; Ritienei, A.; Fogliano, V. Influence of variety and storage on the polyphenol composition of apple flesh. J. Agric. Food Chem. 2004, 52, 6526-6531. [CrossRef]

28. Matthes, A.; Schmitz-Eiberger, M. Polyphenol content and antioxidant capacity of apple fruit: Effect of cultivar and storage conditions. J. Appl. Bot. Food Qual. 2009, 82, 152-157.

29. Soliva-Fortuny, R.; Oms-Oliu, G.; Martin-Belloso, O. Effects of ripeness stages on the storage atmosphere, color and textural properties of minimally processed apple slices. J. Food Sci. 2002, 67, 1958-1962. [CrossRef] 
30. Kader, A.A. Postharvest Technology of Horticultural Crops; UCANR Publications: University of California, Richmond, CA, USA, 2002; Volume 3311.

31. Weibel, F.; Widmer, F.; Husistein, A. Comparison of production systems: Integrated and organic apple production. Part III: Inner quality: Composition and sensory. Schweizer Zeitschrift für Obst-Und Weinbau 2004, $140,10-13$.

32. Crouch, I. 1-Methylcyclopropene (SmartfreshTM) as an alternative to modified atmosphere and controlled atmosphere storage of apples and pears. Acta Hortic. 2003, 600, 433-436. [CrossRef]

33. Farooq, R.A.; Khan, I. Physico-Chemical Quality of Apple cv. Gala fruit Stored At Low Temperature. FUUAST J. Biol. 2012, 2, 103-107.

34. Defilippi, B.G.; Dandekar, A.M.; Kader, A.A. Impact of suppression of ethylene action or biosynthesis on flavor metabolites in apple (Malus domestica Borkh) fruits. J. Agric. Food Chem. 2004, 52, 5694-5701. [CrossRef] [PubMed]

35. Jan, I.; Rab, A. Influence of storage duration on physico-chemical changes in fruit of apple cultivars. J. Anim. Plant Sci. 2012, 22, 708-714.

36. Pre-Aymard, C.; Fallik, E.; Weksler, A.; Lurie, S. Sensory analysis and instrumental measurements of 'Anna' apples treated with 1-methylcyclopropene. Postharvest Biol. Technol. 2005, 36, 135-142. [CrossRef]

37. Clarke, C.J.; McGlone, V.A.; Jordan, R.B. Detection of brownheart in 'Braeburn' apple by transmission NIR spectroscopy. Postharvest Biol. Technol. 2003, 28, 87-96. [CrossRef]

38. Kevers, C.; Falkowski, M.; Tabart, J.; Defraigne, J.; Dommes, J.; Pincemail, J. Evolution of Antioxidant Capacity during Storage of Selected Fruits and Vegetables. J. Agric. Food Chem. 2007, 55, 8596-8603. [CrossRef]

39. Novaković, M.M.; Stevanović, S.M.; Gorjanović, S.Ž; Jovanović, P.M.; Tešević, V.V. Changes of hydrogen peroxide and radical-scavenging activity of raspberry during osmotic, convective and freeze-drying. J. Food Sci. 2011, 76, C663-C668.

40. Vieira, F.G.K.; Borges, G.D.S.C.; Copetti, C.; Di Pietro, P.F.; Nunes, E.C.; Fett, R. Phenolic compounds and antioxidant activity of the apple flesh and peel of eleven cultivars grown in Brazil. Sci. Hortic. 2011, 128, 261-266. [CrossRef]

41. Miletić, M.; Popović, B.; Mitrović, O.; Kandić, M. Phenolic content and antioxidant capacity of fruits of plum cv. 'Stanley' (Prunus domestica L.) as influenced by maturity stage and on-tree ripening. Aust. J. Crop Sci. 2012, 6, 681-687.

42. Nagai, T.; Suzuki, N. Partial purification of polyphenol oxidase from Chinese cabbage Brassica rapa L. J. Agric. Food Chem. 2001, 49, 3922-3926. [CrossRef]

43. Lattanzio, V.; Di Venere, D.; Linsalata, V.; Bertolini, P.; Ippolito, A.; Salerno, M. Low temperature metabolism of apple phenolics and quiescence of Phlyctaena vagabunda. J. Agric. Food Chem. 2001, 49, 5817-5821. [CrossRef] [PubMed]

44. Leja, M.; Marezek, A.; Ben, J. Antioxidant properties of two apple cultivars during long-term storage. Food Chem. 2001, 80, 303-307. [CrossRef]

45. Ilker, R.; Szczesniak, A.S. Structural and chemical bases for texture of plant foodstuffs. J. Text. Stud. 1990, 21, 1-36. [CrossRef]

46. Yoshioka, H.; Aoba, K.; Kashimura, Y. Molecular weight and degree of methoxylation in cell wall polyuronide during softening in pear and apple fruit. J. Am. Soc. Hortic. Sci. 1992, 117, 600-606. [CrossRef]

47. De Smedt, V.; Pauwels, E.; De Baerdemaeker, J.; Nicolaï, B. A microscopic observation of mealiness in apples: A quantitative approach. Postharvest Biol. Technol. 1998, 14, 151-158. [CrossRef]

48. Siddiqui, S.; Brackmann, A.; Streif, J.; Bangerth, F. Controlled atmosphere storage of apples, cell wall composition and fruit softening. J. Hortic. Sci. 1996, 71, 613-620. [CrossRef]

C 2019 by the authors. Licensee MDPI, Basel, Switzerland. This article is an open access article distributed under the terms and conditions of the Creative Commons Attribution (CC BY) license (http://creativecommons.org/licenses/by/4.0/). 